\title{
Japan aims to forge stronger European links
}

David Cyranoski, Tokyo

Government officials in Japan are addressing what they see as a growing problem in science - weak links with Europe and a chronic shortage of European researchers willing to visit Japan.

Although Japan sent more than 32,000 researchers to European universities in 1999, only 6,170 Europeans went to Japanese universities, according to government figures. An analysis of co-authored papers by Masamitsu Negishi of Japan's National Institute of Informatics shows that relations between Japan and the European Union (EU) are by far the weakest link in the US-EUJapan triangle that dominates global research.

Demand from Europeans for fellowships to work in Japan has been moribund, a Tokyo workshop organized last month by the Japan Society for the Promotion of Science (JSPS) was told. The society offers 20 fellowships a year, with benefits including a tax-free stipend of $¥ 400,000(\$ 3,250)$ a month. But in the past three years, only two researchers applied and only one took up the fellowship.

Explanations include low awareness of the fellowships, fear of the language barrier and concerns that Japan is weak in some areas. "There is a perception in Europe that going to Japan is very risky for your career, because Europeans underestimate Japan's research level," says Jan Carlstedt-Duke of the Karolinska Institute in Stockholm.

Japan's plans include the establishment of



Ebb and flow: movement of researchers in 1999.

a JSPS office somewhere in the EU, and the broadening of the ' $2+2$ programme', which allows a researcher to spend two years in Japan with the assurance of two years of funding back home afterwards. The scheme is being piloted in the United Kingdom.

Collaborative institutes, such as the Laboratory for Integrated Micro-Mechatronics Systems, a joint project between France's research agency, the CNRS, and the University of Tokyo, may also be expanded.

But some European researchers blame the lack of a 'collaborative research culture' in Japan. "It is difficult, because of language and other barriers, to have interaction with mentors or with other postdocs and graduate students," says one former postdoc.

Although Japan has some of the bestequipped laboratories in the world, lack of technicians can leave researchers out in the cold. "So you're sitting there with the best machine around and a manual, probably in Japanese. It's hard to move forward," says a European postdoc working on nanostructures at Japan's National Institute of Advanced Industrial Science and Technology, who nonetheless says the scholarship was "a unique opportunity to broaden my understanding of various fields".

Some participants recommended offering fewer but more remunerative scholarships. They said Europeans were deterred by the fact that (unlike Japanese researchers visiting Europe) they won't get their jobs back when they return. Very few visitors to Japan obtain tenured university positions there.

Officials from Japan and the EU will meet later this year to try to agree on concrete steps to address the problem.

Meanwhile, Japan has established a liaison office in Sweden in an attempt to boost Japan's international scientific standing in line with a government-set target of 30 Nobel prizes over the next 50 years.

http://www.fujita3.iis.u-tokyo.ac.jp/ limms

http://www.jsps.go.jp/e-home.htm

\section{Stem-cell research delayed by German ethics council}

\section{Alison Abbott, Munich}

Germany's main university granting agency has bowed to political pressure and agreed to delay its decision on whether to fund research using human embryonic stem cells.

The National Ethics Council, recently established by Chancellor Gerhard Schröder, asked the Deutsche Forschungsgemeinschaft (DFG) to postpone a decision, to give it time to formulate an opinion.

The DFG stated at the beginning of May that it was ready to fund the research. But in response to pressure from the federal research ministry, which called for a full public debate, it delayed until July a decision on its first application, from Oliver Brüstle and Otmar Wiestler at the University of Bonn (Nature 411, 119-120; 2001).

Following the council's request, however, the DFG said it recognized that public debate needed to continue, and agreed to put the decision on ice until at least October.

"From a scientific point of view, nothing has changed our mind about the appropriateness of the DFG funding embryonic stem-cell research," says Claus Bartram, a human geneticist from the University of Heidelberg and a member of the DFG's committee for basic questions in gene research. "But the political pressure has been too great."

Bartram is frustrated by the delays, which he says could mean the shelving of the Bonn team's research plans. Even as the stem-cell debate floods the German media, Bartram says: "No new points of view are being put forward. All the arguments are already on the table. It is time for decisions to be taken."

Germans are particularly sensitive about using embryonic stem cells for research because of human-research abuses during the Nazi era. Many argue that such cells should be subject to constitutional human rights, and would-be researchers have been compared to Josef Mengele, who performed horrific genetic experiments at Auschwitz.

The issue has divided political opinion across party lines, and at the highest levels.
Schröder supports the research, whereas President Johannes Rau, who is also a Social Democrat, opposes it. Wolfgang Clements, the prime minister of Nordrhein-Westfalen, where Bonn is located, has offered to pay for cells to be imported from Israel for Brüstle and Wiestler to use.

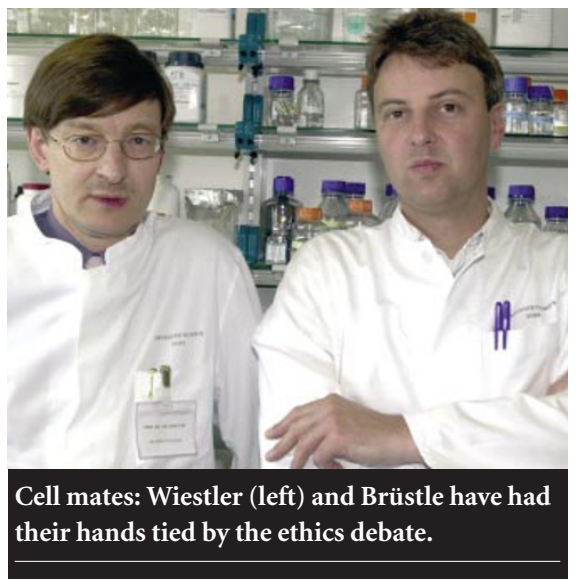

